\title{
Fostering Impactful Research Experiences for Teachers (RETs)
}

\author{
Margaret R. Blanchard ${ }^{1^{*}}$, Victor D. Sampson ${ }^{2}$ \\ ${ }^{1}$ North Carolina State University, Department of STEM Education, Raleigh, North Carolina, U.S.A. \\ ${ }^{2}$ University of Texas at Austin, Department of Curriculum and Instruction, Austin, Texas, U.S.A.
}

Received 1 July 2017 • Revised 9 October 2017 • Accepted 20 October 2017

\begin{abstract}
The National Science Foundation (NSF) in the United States funds Research Experiences for Teachers (RETs) for K-12 science teachers. The RET program seeks to provide science teachers with research experiences so they can provide enhanced science or engineering inquiry experiences for their students. One form of RET that focuses on science pedagogy has resulted in some promising changes in teachers' thinking and lesson design. This case study examines how a cohort of ten secondary science teachers' inquiry conceptions and lesson design changed after participating in a science pedagogy RET, and analyzes the relationship between the components of the program and changes seen in teachers' inquiry conceptions and lessons. Significant changes in teachers' inquiry conceptions and particularly their lessons were a result of teacher adoption of the inquiry-based instructional modeled during the science pedagogy RET. A theory of action is proposed for RET design that would better promote and support teacher learning and foster changes in classroom instruction.
\end{abstract}

Keywords: RET, science inquiry, secondary science teachers, teacher professional development, apprenticeship model

\section{INTRODUCTION}

The Next Generation Science Standards (NGSS) were launched in the United States in 2013 as a way to guide teachers' decisions about curriculum, assessment, instruction, and to better prepare students for the rigors of college and STEM careers (NGSS Release, 2013). The NGSS assert that students need more opportunities to participate in the practices of science while in school in order to be ready to enter a science or science related career and appreciate knowledge gained through science, not simply learn about these practices secondhand (NGSS Lead States, 2013). A review of the literature found teachers' enactment of inquiry-based science practices ranges from often to rare, with concerns that what some teachers were calling inquiry did not correspond to those promoted by US national standards (Capps, Shemwell, \& Young, 2016). Blanchard, Osborne, Wallwork, and Harris (2013) found that science teachers' self-reported use of inquiry-based practices (a definition of inquiry was provided) most depended on their comfort with inquiry. Teaching with inquiry then led to teachers facing obstacles such as the planning time and materials required, the time it took in class, and concerns about their students' interests and or abilities. Interestingly, the more importance the teachers gave to teaching science (predominantly high school teachers), the less likely they were to report teaching science with inquiry. Blanchard et al. recommended that teachers gain access to more professional development for implementing inquiry, resonating with the work of Capps and Crawford (2013); those teachers with well-structured knowledge of inquiry are more likely to use it. It has been noted that many teachers in the United States have not had an opportunity to participate in scientific research as part of their formal education (e.g., Abrams, Southerland, \& Silva, 2007; Anderson, 2007; Capps \& Crawford, 2013). These teachers, as a result, do not understand the practices of science nor how to integrate these practices into their lessons.

Programs that partner teachers and scientists together are considered by many to be a productive way to help teachers develop the knowledge and skills they need to design and implement lessons that give students an opportunity to participate in the practices of science (e.g., Lotter, Harwood, \& Bonner, 2007; MacIsaac \& Falconer, 2002; Roehrig \& Luft, 2004). The underlying assumption of these programs is that those who teach their students how to do science ought to know how to do science and scientists are the most qualified to teach teachers about 


\section{Contribution of this paper to the literature}

- Documents how beliefs and classroom practices of ten science teachers changed after participating in a pedagogy-focused research experience for teachers (RET).

- The beliefs of the teachers who participated in this study were a poor predictor of their instructional practices before and after the pedagogy-focused RET program.

- Changes in the beliefs and practices of the science teachers who participated in this study were associated with a specific feature of the pedagogy-focused RET or a specific event that took place during the program.

- The teachers who participated in this study adopted many elements of the instructional model that were used during the pedagogy-focused RET program, which indicates changing teacher practice also requires a focus on instruction, not just providing research experiences.

- Outlines a new theory of action to guide the design of future RET programs.

how to do science (Feldman, Divoll, \& Rogan, 2009). In order to engage teachers in the practices of science, computer science, and engineering and to enhance their knowledge and skills at the same time, the National Science Foundation (NSF) in the United States funds research experiences for teachers (RETs) (NSF, 2017; Wade, Benson, \& Switzer, 2012). One of the intentions of these programs is to give teachers research experiences under the guidance of practicing scientists during the summer in order to bridge the gap between classroom science and the science done by scientists (e.g., Barnes, Hodge, Parker, \& Coroly, 2006; Dresner \& Worley, 2006; Enderle, Dentzau, Roseler, Southerland, Granger, \& Hughes, 2014; Southerland, Gess-Newsome, \& Johnston, 2003; Pop, Dixon, \& Grove, 2010). The overall goal of RET programs, in other words, is to "build long-term collaborative partnerships between K-12 STEM teachers...in...research and helping them translate their research experiences and new knowledge into classroom activities" (NSF, 2017, n. p.).

Science RET programs can be grouped into one of two broad categories depending on what teachers are expected to do during the program (Enderle et al., 2014). The first category is a science research focused model and the second category is a science pedagogy focused model. In the more traditional, science research focused model of a RET, teachers are assigned a mentor scientist and are expected to work in his or her lab and study whatever the mentor is studying. The teachers in these programs are expected to gain research experience and a better understanding of inquiry by participating in an on-going study (e.g., Barnes et al., 2006). In a science pedagogyfocused RET, which is less common, teachers have an opportunity to develop their own research questions and engage in scientific inquiry from inception through the presentation of findings (Blanchard, Southerland, \& Granger, 2009; Enderle et al., 2014). In this less traditional design, the teachers' own observations of the natural world and subsequent questions or problems arising from it guide the inquiry process (e.g., Lotter et al., 2007). The teachers in these programs are also taught about one or more inquiry-based instructional approaches as part of the experience.

Although thousands of teachers have participated in RETs, little empirical research examines the value of RETs or other research experiences as a way to improve student achievement or to promote and support inquiry-based instruction in the classroom (Capps, Crawford, \& Constas, 2012; Silverstein, Dubner, Miller, Glied, \& Loike, 2009). In one of the few studies that examined the effect of a RET on student achievement, Silverstein et al. (2009) followed 145 teachers who participated in science research focused RET program at Columbia University between 1994 and 2005. They found that students of the teachers who participated in the RET program scored $10 \%$ higher on state standardized grade level assessments than non-RET teachers 3-4 years after the program and the attrition rates for these teachers was lower. These authors, however, did not examine the teaching practices of the teachers before or after the RET program nor did they attempt to control for selection effects (e.g., the teachers who participated were already good teachers) or the influence of other professional development experiences. The amount of the increase in student achievement that can be directly attributed to the RET program at Columbia University, as a result, is uncertain.

A more recent study by Enderle et al. (2014) compared how the two types of RETs affected teachers' beliefs about teaching, pedagogical discontentment (level of dissatisfaction with one's current teaching practices), selfefficacy, and classroom practice. The elementary, middle, and high school teachers in the study $(N=100)$ participated in either a research-focused or a pedagogy-focused RET for six weeks. The results of that study indicated that both of the RET programs had a positive impact on the teachers' beliefs about teaching, the amount of pedagogical discontentment they felt, and their self-efficacy. The results, however, were more dramatic for the teachers in the science pedagogy-focused RET program. In addition, the teachers in the science pedagogy-focused RET changed how they designed inquiry-based lessons, whereas the teachers in the science research-focused RET did not. In a follow-up study, Southerland, Granger, Hughes, Enderle, Ke, Chaminade...Tekkumru-Kisa (2016) used structural equation modeling to analyze the data on 106 elementary, middle and high school teachers in both the research-focused RET and the pedagogy-focused RET. They found that personally relevant research experiences 
were more powerful forces than necessarily 'authentic' science experiences. The authors emphasize the need to capture teachers' affective states prior to the professional development experiences and that there may be multiple pathways to influencing changes in teachers' practices. This study follows up on the Southerland et al. work by studying changes (or lack of changes) in a pedagogically-focused RET that included personally relevant experiences. We seek to critically examine the current RET model as a vehicle for teacher professional development, through the lens of an apprenticeship model.

\section{THEORETICAL FRAMEWORK}

Teachers who participate in RETs come from a wide range of backgrounds, which includes the extent to which they have previously conducted scientific research (e.g., Blanchard, Southerland, Osborne, Sampson, Annetta, \& Granger, 2010; Enderle et al., 2014). When working with scientists in a science research-focused RET setting, the work of teachers, who often are unfamiliar with the nature of scientific research and lack the research skills of practicing research scientists, is often viewed as an apprenticeship. From this theoretical perspective, individuals working with a practicing research scientist progress through a series of predictable stages as they develop their research skills, from Novice Researcher to Proficient Technician to Knowledge Producer (Lave \& Wenger, 1991). Novice Researchers have had little or no experience with scientific research; Proficient Technicians, who have gained a level of research experience and technical skills, are able to design their own investigations and collect data; and Knowledge Producers are able to contribute to the literature by developing explanations, arguing from evidence, and communicating information. They also are able to function as colleagues for other Knowledge Producers and critique their ideas and methods. Feldman et al. (2009) applied this model to teachers who are learning to do science during a research experience. From this perspective, teachers generally enter a RET as a Novice. The teachers are then given an opportunity to learn about inquiry from scientists who are actual Knowledge Producers and perhaps the teachers become Proficient Technicians by the end of the experience.

This theoretical perspective has two important implications for the design of RET programs. First, teachers must have opportunities to participate in the practices of science to learn about them. University research laboratories, as a result, are ideal setting for learning about the practices of science because the people who run those labs are knowledge producers. These individuals are responsible for investigating natural phenomena by engaging in the practices of science and are assisted by proficient technicians and novices. Second, novices must develop an understanding of what makes certain aspects of research more productive or useful than others within a particular discipline. The knowledge producers and proficient technicians understand what makes aspects of research more productive and useful so they can share this knowledge with the novices as part of the research experience. By focusing on both the how and the why, novices can develop a more nuanced understanding of the practices of science over time.

The theory of action underlying science research-focused RET programs are often well aligned with the assumptions underlying this theoretical perspective. An example of a theory of action that is based on these assumptions, which guides the design of most traditional science research-focused RET programs, is provided in Figure 1. In this example, the malleable factor, or the characteristics of a teacher that is the target of the intervention, is knowledge of scientific research. The intervention is the research apprenticeship and the proximal outcome is improved teacher knowledge of scientific research. The teacher is then expected to use this knowledge to create and implement lessons that give students an opportunity to participate in the practices of science. This component of the theory of action is a mediating factor, because the nature of the lessons affect what students learn, the final outcome of the program. 


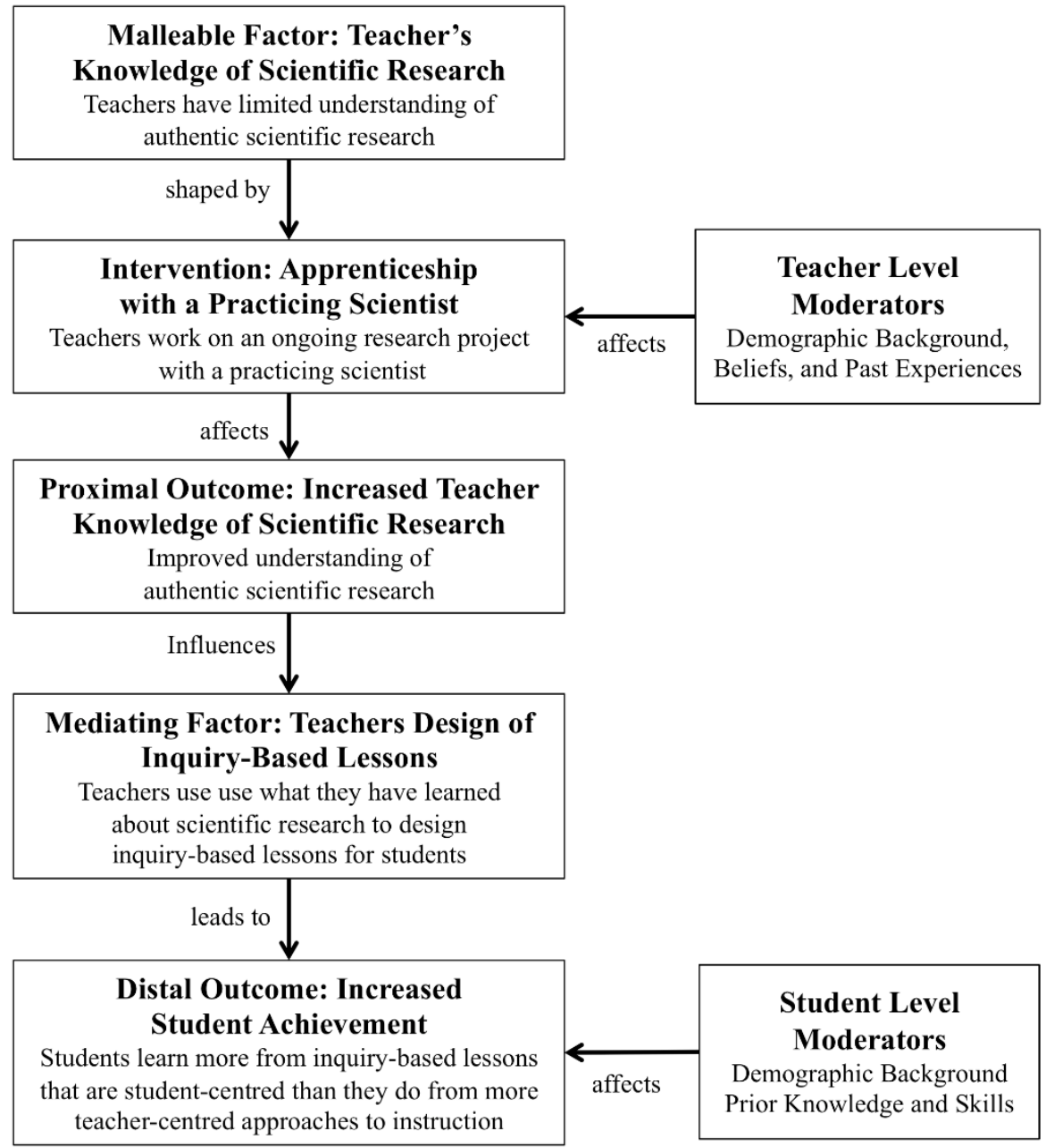

Figure 1. The theory of action underlying a science research-focused RET model

Current research that examines the outcomes of science research-focused RETs, as noted earlier, suggests that the intervention of a research experience for teachers can have a positive impact on teacher knowledge of inquiry (Southerland et al., 2016) but modest to few influences on the changes in teacher practice (Enderle et al., 2014; Sadler, Burgin, McKinney, and Ponjuan, 2010). Few impacts on students have been documented (Capps et al., 2012; Silverstein et al., 2009). It is therefore important to consider how this theory of action might be revised in order to improve the likelihood that a RET program will result in changes in teacher practice and increases in student achievement. One productive way to identify potential ways to revise this theory of action is to examine specific RET programs that have resulted in substantial changes in teacher practice, such as a science-pedagogy focused RET in the Enderle et al. (2014) study, to better understand how the various components of this unique type of RET program contribute to changes in different aspects of teacher conceptions of inquiry and classroom practices. These findings can then be used to develop a new theory of action that can be used to guide the development of future RET programs.

\section{OBJECTIVE AND RESEARCH QUESTIONS}

The main objective for this study, given our theoretical framework, was to examine how teacher thinking and lesson design changed after teachers participated in a science pedagogy RET experience. Therefore, the research questions guiding this study were:

- How did the teachers' conceptions of inquiry change after they participate in a science pedagogy-focused RET?

- How did the nature of the inquiry-based lessons developed by these science teachers change after they participate in a science pedagogy-focused RET?

- Which aspects of the RET program seem to contribute to teachers' changes? 


\section{METHODS}

\section{The Research Setting}

The RET program in this study was called the Marine Ecology for Teachers Program, which is a professional development program funded by the US National Science Foundation and offered through a major university in the southeast United States. This program was designed to facilitate teachers' understanding about inquiry both as a method for scientific research and as a strategy for teaching science. The resulting program engaged teachers in meaningful scientific research and a concurrent, in-depth study of the inquiry-based instructional approach modelled by the program. The goal was for teachers to understand the model of inquiry that they conducted well enough to translate that model to a lesson of their own design and appropriate to their classrooms, then to implement the lesson with their students. The RET design reflects the research that suggests that research experience offered in tandem with reflection on the teaching of inquiry is essential for teachers to internalize aspects of inquiry (Luft, 2001; Roehrig \& Luft, 2004; Schön, 1987).

In order to gain entry to the program, each teacher was required to videotape an inquiry-based lesson and complete a questionnaire describing her or his conceptions of inquiry. The directions for the videotape were purposefully vague in an attempt to have teachers submit what they currently considered 'inquiry.' Thus, the range of lessons submitted by teachers was disparate, and some of them were not laboratory based. No other criteria were required, and admission was 'first come, first served' until all 24 slots were filled by a mixture of elementary, middle, and secondary teachers who taught some science.

In the RET program, three marine scientists and two master teachers worked alongside approximately 24 teachers in scientific research and pedagogy sessions throughout the six-week program at a biological field station situated on the ocean. One of the premises underpinning the original design of the RET program was that teachers need to experience the entire scientific inquiry process, from initial observations through development of a hypothesis, to experimentation, interpretation of findings, and the sharing of findings. Resonant with the recommendations of Park, Jang, and Kim (2009), the program involved teachers working in research groups as they made decisions throughout the process of the inquiry investigation. The science pedagogy approach used by the scientists was to make the inquiries that take place during the RET authentic not only to science (Chinn \& Malhotra, 2002) but also to the participants (Abrams, Southerland, \& Silva, 2007). In that way, it differed from the more traditional science research approach to an RET, in which a teacher joins a research project already in progress in the laboratory of a scientist, and so the activity may be authentic to science but not authentic to the participating teacher (e.g., Barnes et al., 2006; Southerland et al., 2016).

In an introductory lesson at the beginning of the RET program, teachers made observations about estuarine organisms (e.g., fiddler crabs and great blue herons). The researchers gave different groups of teachers a different research question, modelling how to word research questions so that they could be answered empirically. The teachers then worked closely in small groups, supported and questioned by the three marine scientists and two science educators, to refine their initial question and to develop a plan for collecting data. The marine scientists also lead a "tool talk" during this stage to demonstrate equipment and techniques that might be useful to the teachers during their inquiries, such as how to simulate wave action in a tank. Research protocols were tried out and refined by teachers, with the scientists asking about teachers' thinking, thereby modelling what sort of questions the teachers should be asking. Researchers worked with the teacher teams to encourage their thinking about whether data the teachers collected would indeed answer the teacher team's research question. As a final step to their first investigation, teams developed PowerPoint presentations to share their findings, which they delivered to the entire group. This step was included as part of the process in order to model how science is presented at conferences, and to understand the thinking that other teachers had done as they developed their research projects. Next, each team, with support, designed and carried out a second investigation.

Concurrent with the marine science research experience, the teachers engaged in an intensive reflection on the inquiry modelled by the lead scientist. Teachers wrote out all of the steps that they, as learners, had taken, and all of the steps of the lead scientist, acting as the teacher. Teachers shared what they wrote, and reflected together on each step. The stages of inquiry modelled in the RET Program and discussed in the inquiry on inquiry sessions consisted of these six stages (see Figure 2). The intention of the component of the program was for the teacher participants to experience inquiry and to understand the steps of one model of inquiry, as a way to see how they might adapt that model to their classroom teaching. 


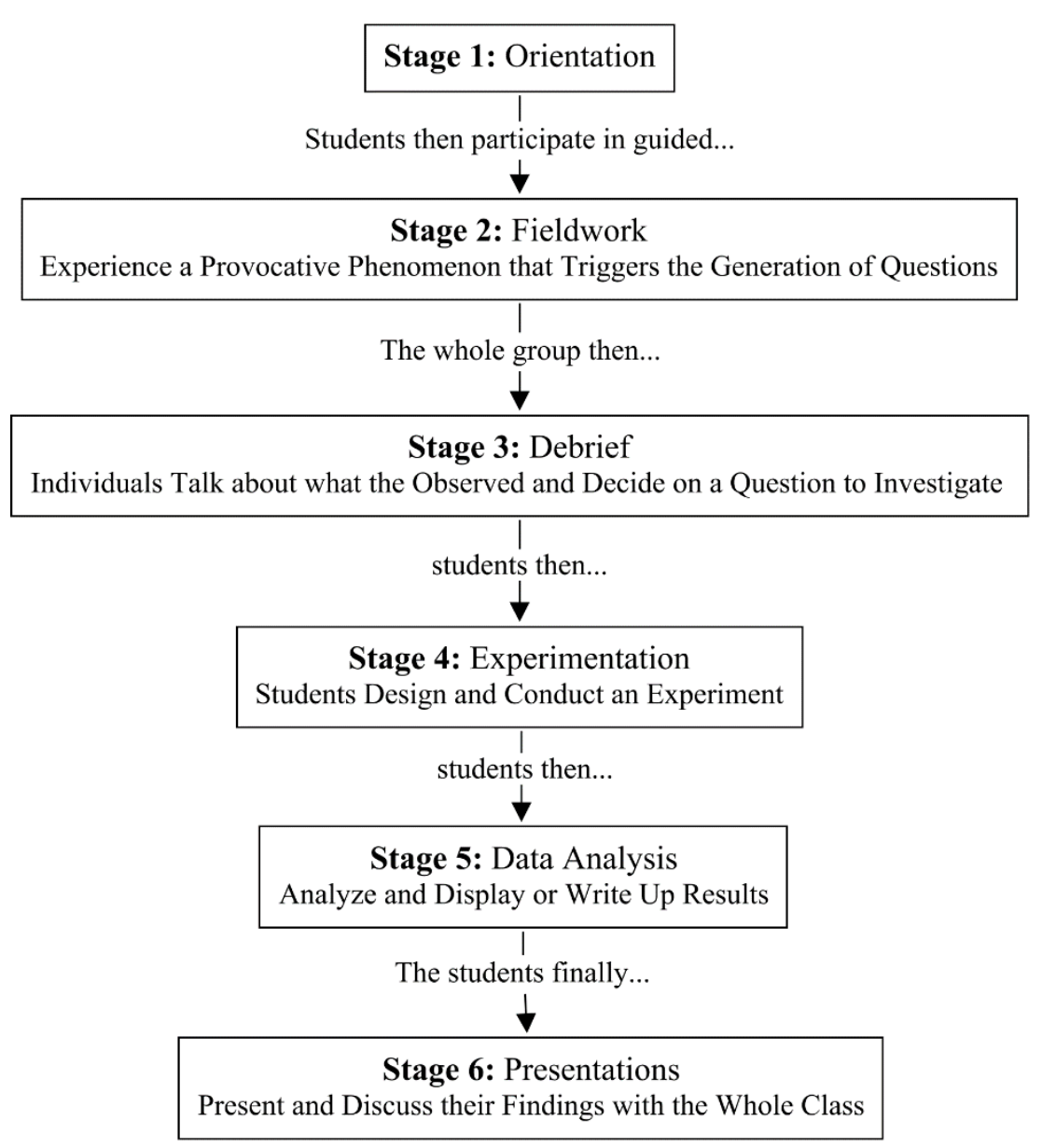

Figure 2. The stages of the inquiry-based instructional approach that was a focus of the "inquiry on inquiry" sessions during the science-pedagogy focused RET

The RET program culminated with each teacher adapting a lesson from his or her content area using the model of inquiry they experienced in the program. Program staff helped teachers to think through how their lesson needed to be designed in order to employ all of the stages they had experienced in the RET program. All of the lessons teachers developed were found by program staff to be appropriate for inquiry, although during initial stages of development, most teachers in the program were unclear of how to take a lesson and adapt it to match the stages of the program model. For many of the teachers this was an intensive experience, because up until this point they had not yet applied their learning to a new situation. Many revisions were required of the lessons, and teachers 'tried out' parts of their lessons (usually the provocative phenomenon, which is an observation intended to stimulate the development of research questions) with program participants to see if it would work. Teachers were asked to teach the inquiry based lesson that they had developed for the RET with their students, videotape it, and answer a post-program questionnaire about their conceptions based on their inquiry-based lesson.

\section{The Participants}

Of the 24 teachers who participated in the RET program, eleven were elementary teachers and thirteen were secondary-science teachers. All of the middle and high school teachers who participated in the RET program were invited to participate in this study but only ten of them agreed to participate. The ten participants in this study were diverse in terms of age, years of experience, location, subjects taught, and content developed for their inquiry-based lesson. Table 1 provides an overview of the demographic data collected from these teachers. 
EURASIA J Math Sci and Tech Ed

Table 1. RET Teacher Participants

\begin{tabular}{|c|c|c|c|c|c|c|c|c|c|}
\hline \multirow{2}{*}{ Name } & \multirow{2}{*}{ Ethnicity } & \multirow{2}{*}{ Gender } & \multirow{2}{*}{ Age } & \multirow{2}{*}{ Degree(s) } & \multirow{2}{*}{$\begin{array}{c}\text { Years } \\
\text { Teaching }\end{array}$} & \multirow{2}{*}{$\begin{array}{l}\text { Teaching } \\
\text { Assignment }\end{array}$} & \multirow{2}{*}{$\begin{array}{c}\text { School } \\
\text { Description }\end{array}$} & \multicolumn{2}{|c|}{ Lesson Topic } \\
\hline & & & & & & & & Pre (Days) & Post (Days) \\
\hline Sherilyn & AA & Female & 32 & B.S. Biology & 5 & $10^{\text {th }}$ Biology & $\begin{array}{l}\text { Urban Public } \\
2200 \text { students }\end{array}$ & Genetics (3) & $\begin{array}{c}\text { Seed } \\
\text { Germination (3) }\end{array}$ \\
\hline Patrisha & AA & Female & 48 & $\begin{array}{l}\text { B.S. Criminology } \\
\text { M.S. Spec Ed }\end{array}$ & 15 & $\begin{array}{c}6^{\text {th }} \text { science (special } \\
\text { education) }\end{array}$ & $\begin{array}{l}\text { Urban Public } \\
850 \text { students }\end{array}$ & Mosquitoes (1) & $\begin{array}{c}\text { Plant } \\
\text { Growth (5) }\end{array}$ \\
\hline Phillip & AA & Male & 32 & B.S. Biochemistry & 4 & $\begin{array}{c}11^{\text {th }} \text { Chemistry \& } \\
9^{\text {th }} \text { Physical }\end{array}$ & $\begin{array}{l}\text { Rural Public } \\
1200 \text { students }\end{array}$ & Gas Laws (2) & $\begin{array}{c}\text { Bottle } \\
\text { Rockets (11) }\end{array}$ \\
\hline Gloria & AA & Female & 43 & B.S. Biology & 8 & $\begin{array}{c}9^{\text {th }} \text { Honours } \\
\text { integrated science }\end{array}$ & $\begin{array}{c}\text { Urban Public } \\
1000 \text { students, }\end{array}$ & $\begin{array}{l}\text { Egg Structure } \\
\text { \& Function (1) }\end{array}$ & $\begin{array}{c}\text { Soil } \\
\text { Absorption (4) }\end{array}$ \\
\hline Sage & EA & Female & 33 & B.S. Culinary Arts & 4 & $10^{\text {th }}$ Food Prep & $\begin{array}{l}\text { Suburban Public } \\
1350 \text { students }\end{array}$ & Reactions (1) & $\begin{array}{c}\text { Mold } \\
\text { Growth (3) }\end{array}$ \\
\hline Mason & EA & Male & 36 & $\begin{array}{l}\text { B.S. Biology } \\
\text { M.S. Science } \\
\text { Education }\end{array}$ & 4 & $\begin{array}{c}10^{\text {th }} \text { Biology } \\
11^{\text {th }} \text { Marine Science }\end{array}$ & $\begin{array}{l}\text { Urban Public } \\
1802 \text { students }\end{array}$ & Exam Review (1) & $\begin{array}{c}\text { Wave } \\
\text { Action (8) }\end{array}$ \\
\hline Betsy & EA & Female & 34 & $\begin{array}{l}\text { B.S. Secondary } \\
\text { Science Ed }\end{array}$ & 11 & $\begin{array}{l}7^{\text {th }} \text { Integrated } \\
\text { Science }\end{array}$ & $\begin{array}{l}\text { Suburban Public } \\
630 \text { students }\end{array}$ & $\begin{array}{c}\text { Physical \& Chemical } \\
\text { Changes (1) }\end{array}$ & $\begin{array}{l}\text { Light and } \\
\text { Colour (3) }\end{array}$ \\
\hline Charity & EA & Female & 25 & $\begin{array}{l}\text { B.S. Biology } \\
\text { M.S. Biology }\end{array}$ & 2 & $\begin{array}{l}9^{\text {th }} \text { Aquatic } \\
\text { Science }\end{array}$ & $\begin{array}{l}\text { Suburban Public } \\
500 \text { students }\end{array}$ & $\begin{array}{c}\text { Betta Fish Behaviour } \\
\text { (1) }\end{array}$ & $\begin{array}{c}\text { Betta Fish } \\
\text { Behaviour (4) }\end{array}$ \\
\hline Max & EA & Male & 31 & $\begin{array}{l}\text { B.S. English } \\
\text { Education }\end{array}$ & $\begin{array}{c}7 \text { (3 in } \\
\text { science) }\end{array}$ & $\begin{array}{c}\text { 10th grade } \\
\text { Integrated Science }\end{array}$ & $\begin{array}{l}\text { Urban Public } \\
1800 \text { students }\end{array}$ & $\begin{array}{l}\text { Shark organ } \\
\text { structures \& } \\
\text { functions (1) }\end{array}$ & Soil filtration (1) \\
\hline Jamilla & AA & Female & 46 & $\begin{array}{l}\text { B.S. Biology } \\
\text { M.S. Curriculum } \\
\text { \& Instruction }\end{array}$ & 20 & $\begin{array}{l}8^{\text {th }} \text { life science } \\
6^{\text {th }} \text { life science }\end{array}$ & $\begin{array}{c}\text { Suburban Private } \\
\text { (Christian) } \\
300 \text { students }\end{array}$ & Plant Tropisms (1) & $\begin{array}{l}\text { Plant Tropisms } \\
\text { (3) }\end{array}$ \\
\hline
\end{tabular}

Note: $\mathrm{AA}=$ African American; $\mathrm{EA}=$ European American.

\section{Data Sources and Analysis}

Teachers' Inquiry Conceptions. The participating teachers were required to respond to questions about the lessons they taught, both pre and post program. These questions (described as a questionnaire from this point forward) asked the teachers to describe key characteristics of the inquiry, their primary learning goals for the lesson, how effective they thought the lesson was, and future intended use of the lesson and plans for using inquiry.

The teachers' descriptions of their classroom activities were very 'practical' in nature (Gallagher \& Parker, 1995). These responses were coded into categories of "content", "assessment," "teacher actions," and "student actions" based on the Teacher/Learner Inquiry Continuum (TLIC; Blanchard, 2006; see Table 2). The first author coded each sentence or phrase from the pre and post program questionnaire responses for these teachers with each of the categories. The teachers' responses within the different categories were then coded based on the learner-centred to teacher-centred continuum of the TLIC. For example, a response such as, "teachers will facilitate students' learning" was first coded into the category "teacher actions" because it focused on what teachers do within the classroom. This same response was then coded as a somewhat teacher centred conception of inquiry because the teacher role was foregrounded, but the response mentioned students in relation to the role of the teacher.

The first author used several checks to ensure consistency and reliability of the codes. First, she blinded the responses prior to coding, including not knowing if it was a response was from a questionnaire that a teacher completed before or after the RET program. All the responses for a person were thus separated and coded independent from one another, in a random order. Next, she created a coding protocol that indicated how the teachers had talked about their work in relation to students (from teacher-centred to student-centred) and referred to this during the coding process. After coding data from several teachers, she peer debriefed (Erlandson, Harris, Skipper, \& Allen, 1993) with an expert science education researcher to check that the coding was consistent and made sense. After half of the data was coded, the researcher went back and re-coded a random half of the data again, and compared it to her original codes, to check for internal consistency and essentially serve as her own cocoder. Virtually no discrepancies occurred in the coding of the data, despite the prolonged number of months over which the analyses took place. Finally, after confirming that the process was consistent, she then completed these analyses, whose codes corresponded to the summaries in Table 2. 
Table 2. Teacher Learner Inquiry Rubric (Blanchard, 2006)

\begin{tabular}{|c|c|c|c|c|}
\hline $\begin{array}{l}\text { Aspect of } \\
\text { Inquiry }\end{array}$ & $\begin{array}{l}\text { Learner } \\
\text { Centred }\end{array}$ & $\begin{array}{c}\text { Somewhat } \\
\text { Learner Centred }\end{array}$ & $\begin{array}{c}\text { Somewhat } \\
\text { Teacher Centred }\end{array}$ & $\begin{array}{l}\text { Teacher } \\
\text { Centred }\end{array}$ \\
\hline $\begin{array}{l}\text { Inquiry } \\
\text { Metaphors } \\
\text { and } \\
\text { Definitions }\end{array}$ & $\begin{array}{l}\text { Focus on student learning, } \\
\text { hands-on doing, } \\
\text { exploration, observations, } \\
\text { and student-generated } \\
\text { questions. }\end{array}$ & $\begin{array}{l}\text { Students take lead on some } \\
\text { aspects, such as predictions and } \\
\text { trying to answer questions. } \\
\text { Student prior knowledge and } \\
\text { curiosity a focus. }\end{array}$ & $\begin{array}{l}\text { Teacher as facilitator, } \\
\text { guided inquiry. }\end{array}$ & $\begin{array}{l}\text { What scientists' do, } \\
\text { removed from students. } \\
\text { Fixed "scientific } \\
\text { method." }\end{array}$ \\
\hline Content & $\begin{array}{l}\text { Connections to real world, } \\
\text { ideas are related, } \\
\text { connections to students' } \\
\text { lives, interactive. }\end{array}$ & $\begin{array}{l}\text { Content involves some student } \\
\text { interaction, partially focused on } \\
\text { processes, some relevance to } \\
\text { students. }\end{array}$ & $\begin{array}{l}\text { Content delivered by } \\
\text { teacher, but some } \\
\text { student participation, } \\
\text { responding to questions. }\end{array}$ & $\begin{array}{c}\text { No examples or } \\
\text { interconnections, } \\
\text { focused on factual } \\
\text { content, delivery, no } \\
\text { hand-on content, focus } \\
\text { on state standards/tests. }\end{array}$ \\
\hline $\begin{array}{l}\text { Teacher's } \\
\text { Actions }\end{array}$ & $\begin{array}{l}\text { Teachers act in support of } \\
\text { student learning, actions. }\end{array}$ & $\begin{array}{l}\text { Students encouraged to ask } \\
\text { questions, allow students to } \\
\text { make mistakes, guide students } \\
\text { in their thinking. }\end{array}$ & $\begin{array}{c}\text { Address student } \\
\text { questions in discussion, } \\
\text { use questions, ask } \\
\text { student questions on } \\
\text { factual material, monitor } \\
\text { students. }\end{array}$ & $\begin{array}{c}\text { Direct instruction, } \\
\text { identify misconceptions, } \\
\text { monitor behaviour, focus } \\
\text { students on content. }\end{array}$ \\
\hline Assessment & $\begin{array}{c}\text { Multiple forms of } \\
\text { assessment, some } \\
\text { formative; focus on } \\
\text { investigation findings and } \\
\text { presentations. }\end{array}$ & $\begin{array}{l}\text { Students generate } \\
\text { presentations with teacher } \\
\text { guidance, mix of factual and } \\
\text { investigative knowledge } \\
\text { accounting for grade. }\end{array}$ & $\begin{array}{l}\text { Grades for "on task" } \\
\text { behaviour and for } \\
\text { answering teachers' } \\
\text { questions, focus is on } \\
\text { matching teachers' } \\
\text { knowledge. }\end{array}$ & $\begin{array}{l}\text { Tests and quizzes over } \\
\text { factual material. }\end{array}$ \\
\hline $\begin{array}{l}\text { Students' } \\
\text { Actions }\end{array}$ & $\begin{array}{c}\text { Students actively } \\
\text { participate in learning, } \\
\text { experimentation, creating } \\
\text { questions, etc. }\end{array}$ & $\begin{array}{l}\text { Students assume more } \\
\text { responsibility, make predictions, } \\
\text { gather data, learn content, use } \\
\text { science skills. }\end{array}$ & $\begin{array}{l}\text { Dialogue so teacher can } \\
\text { gauge problems, adjust } \\
\text { thinking to teacher } \\
\text { ideas. }\end{array}$ & $\begin{array}{c}\text { Answer teacher } \\
\text { questions, review for a } \\
\text { grade. }\end{array}$ \\
\hline $\begin{array}{l}\text { Other } \\
\text { Factor(s) } \\
\text { mentioned } \\
\text { by Teacher }\end{array}$ & $\begin{array}{l}\text { Time didn't allow for more } \\
\text { in-depth student } \\
\text { investigations, student } \\
\text { interest promotes } \\
\text { retention. }\end{array}$ & $\begin{array}{l}\text { Students assumed more } \\
\text { responsibility for their learning. }\end{array}$ & $\begin{array}{l}\text { Students thought it was } \\
\text { social time, lab took a lot } \\
\text { of class time. }\end{array}$ & $\begin{array}{l}\text { Not enough teacher } \\
\text { control without } \\
\text { handouts. }\end{array}$ \\
\hline
\end{tabular}

Teacher inquiry practices. The pre program lessons encompassed a broad range of classroom activities, not necessarily inquiry per se, but rather a snapshot of typical classroom practice by each teacher, or what they believed may be an example of an inquiry. Although these initial classroom recordings might be considered a limitation of this study, triangulation of multiple data sources and prolonged engagement with teachers suggest these data to be reliable indicators of teachers' instructional practices prior to the program. Post program, the follow-up inquirybased lessons, planned during the RET, were recorded via an audio recorder carried by the teacher and a camcorder that captured the class as a whole.

We coded the teachers' inquiry practices using the Science Teacher Inquiry Rubric (STIR). The STIR is an instrument that accounts for how student- or teacher-centred an entire investigation is, based upon who: 1) generates the question; 2) plans the investigation; 3) collects and analyses data; 4) formulates hypotheses; 5) connects findings to the literature; and 6) plans for the communication of results (Bodzin \& Beerer, 2003). The STIR rubric has four options for each aspect of inquiry that reflects a continuum, with one end of the continuum being "learner-centred" and the other being "teacher-centred." There is also a "no evidence observed" category.

The analysis of the STIR instrument was coded by two independent researchers (authors) involving the following steps: 1) coding what the teacher and student had done during the inquiry investigation on separate instruments; 2) comparing the codes and then noting any discrepancies in coding; 3) using classroom transcription (from video recordings) to review what had occurred; and, 4) re-coding one negotiated STIR instrument between the researchers. On the first pass, the researchers came to agreement an average of $78 \%$ of the time, then discussed until 100\% agreement was met at the second pass (Patton, 2002). Two-way contingency table analyses were then conducted in order to determine if there were any statistically significant differences in each aspect of inquiry pre to post program (Green and Salkind, 2005). 


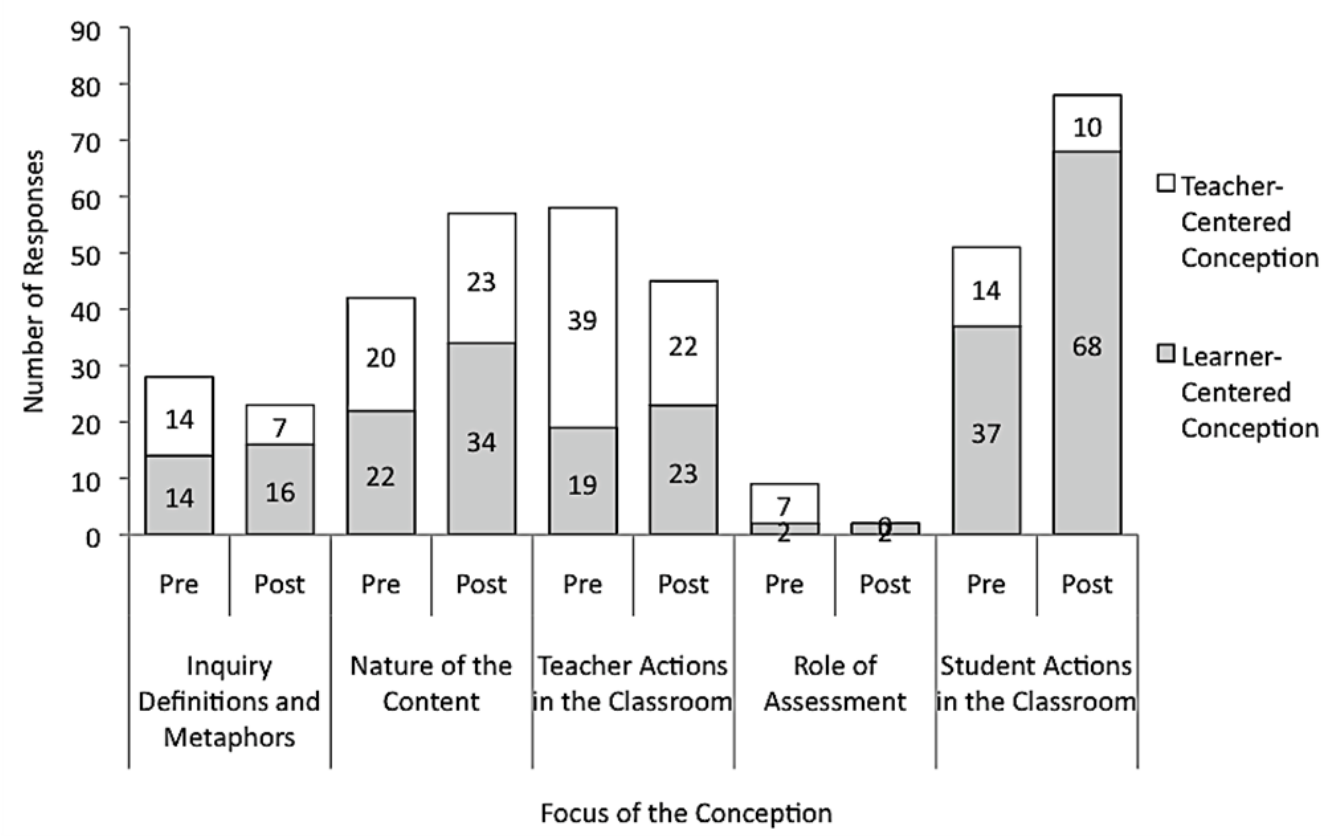

Figure 3. Number of teacher-centred and learner-centred responses in response to the items on the questionnaire

\section{FINDINGS}

The presentation of our findings is divided into three parts with each subsection addressing a specific research question. Each subsection will include a brief overview of the analysis that was conducted in order to answer the research question and the results of that analysis.

\section{How did the Teachers' Conceptions of Inquiry-Based Science Instruction Change after Participating in a Science Pedagogy-Focused RET Program?}

We looked for changes in the nature of the responses teachers provided on the pre and post program questionnaire in order to examine how the teacher's conceptions of inquiry changed after the RET. The teachers' responses on the questionnaire, as noted earlier, were related to five categories. The first was their definitions and metaphors for inquiry. The second was the nature of the content to be learned. The third was related to how they described teacher actions in the classroom during the lesson. The fourth was how they viewed the role of assessment during the lesson. The fifth, and final category, was how they described the actions of the students in the classroom. These were then coded as being either a teacher-centred or learner-centred conception of inquiry using the Teacher Learner Inquiry Rubric (Blanchard, 2006). The results of this analysis are provided in Figure 3.

Post program, the teachers wrote more responses on the questionnaires about the nature of the content (e.g., what needs to be taught and why) and what students should be doing inquiry (i.e., student actions). Additionally, post program, teachers expressed fewer comments about what counts as inquiry (i.e., definitions and metaphors) or teacher actions in the classroom during inquiry. Overall, the role of assessment during inquiry-based instruction was rarely discussed. Regardless of category, however, a greater proportion of the comments made by these teachers were learner-centred after the program. For example, on the pre program questionnaire in response to the question, What are the primary learning goals for this investigation? Sherilyn wrote,

The lesson objectives were to predict the possible outcomes of phenotypes in a genetic cross from
genotypes of the parents and predict the mode of inheritance. Students were to create a Punnett square
and complete the problem solving handouts in their groups.

This response was coded as somewhat teacher centred because of what needs to be taught and what the students will do was based on the teacher expectations. It was clear from this response that her views focused on students completing an assignment rather than giving them an opportunity to design an investigation, decide how to analyse data, or develop an explanation for why or how something happens. Her post program response to the question, however, indicated that she wanted her students to have more choice during the lesson. Sherilyn wrote, 
Table 3. Results of for the teacher conceptions $2 \times 2$ contingency table analysis

\begin{tabular}{ccccc}
\hline Comparison & $\boldsymbol{\chi}^{\mathbf{2}}$ & $\mathbf{N}$ & $\mathbf{p}$ & Cramer's $\boldsymbol{V}$ \\
\hline Overall (all responses) & 16.00 & 393 & $<.001$ & .20 \\
\hline Inquiry definitions and metaphors & 2.00 & 51 & .16 & - \\
\hline Nature of the content & 0.52 & 99 & .47 & - \\
\hline Teacher actions in the classroom & 3.53 & 103 & .06 & .04 \\
\hline Role of assessment & 4.28 & 11 & .04 & .19 \\
\hline Student actions in the classroom & 4.36 & 129 & & .39 \\
\hline
\end{tabular}

The primary learning goals for this lab were the following: [For students] [t]o learn how to ask meaningful questions and conduct careful investigations. To use the scientific method steps to design and conduct an experiment.

This response was coded as student centred because of she framed the response in terms of what the students would be learning. It was clear from this response that her focus for the sample inquiry lesson was different. Instead of asking her students to complete a worksheet, her goal was to give students an opportunity to plan and carry out an investigation.

In order to determine if the differences observed in the proportion of comments that were coded as teachercentred and learner-centred pre and post program were significant or not, we conducted a $2 \times 2$ contingency table analysis for all the responses overall and for the responses in each category. The two variables included in each analysis were time with two levels (pre and post program) and aspect with two levels (teacher-centred and learnercentred). The results of the six comparisons are provided in Table 3.

The results of this analysis indicate that there was a significant pre to post difference in the proportion of teacher-centred and learner-centred responses overall, $\chi^{2}(1, N=393)=16.00, p=<.001$, Cramer's $V=.2$, but only two of the five categories of teacher conceptions were significant when they were tested alone. The teachers gave a greater proportion of learner-centred responses when describing student actions in the classroom, $\chi^{2}(1, N=129)=$ $4.36, p=.04$, Cramer's $V=.19$, and the role of assessment in during an inquiry, $\chi^{2}(1, N=11)=4.28, p=.04$, Cramer's $V=.39$ but not when defining inquiry, discussing content, or describing teacher actions. It is important to note, however, that there were very few responses that dealt with assessment before or after the program and the low overall number of responses might therefore bias the results of that test. It is also important to note that there was a large difference in the proportion of learner-centred responses in the teacher action category after the program $(51 \%)$ when compared to the proportion of learner-centred responses before the program (33\%), although this difference was not statistically significant, $\chi^{2}(1, N=103)=3.53, p=.06$.

These results, when taken together, suggest that these teachers' conceptions were more learner-centred overall (given the significant difference in the proportion of learner-centred responses pre to post program) and the teachers seemed more concerned with the nature of the content and student actions after the program (given the increase in the overall number of comments in these categories). These results also suggest that these teachers were less concerned with the role of assessment during inquiry-based instruction and what the teacher should be doing during an inquiry-based lesson.

\section{How did the Inquiry-Based Lessons Submitted by these Science Teachers Change after the Science Pedagogy-Focused RET Program?}

In order to determine the extent to which the inquiry-based lessons submitted by the teachers changed pre to post program, we calculated the number of lessons that included each essential aspect of inquiry (as defined by the National Research Council, 2000) and then determined if the included aspects were teacher-centred or learnercentred. The lessons, as noted earlier, were coded using the Science Teacher Inquiry Rubric (Bodzin \& Beerer, 2003) to facilitate this pre- to post-program comparison. The results of this analysis are provided in Figure 4. Overall, more of the of the post program lessons engaged students in scientifically orientated questions (post 10; pre 6), had students plan an investigation (post 10; pre 6), required learners to give priority to evidence (post 10; pre 5) and to formulate explanations from evidence (post 10; pre 6), and enabled students to communicate and justify a proposed explanation (post 10; pre 0). More of the lessons at the beginning of the program, however, included an opportunity for students to evaluate a proposed explanation in light of other explanations (pre 4; post 1). 


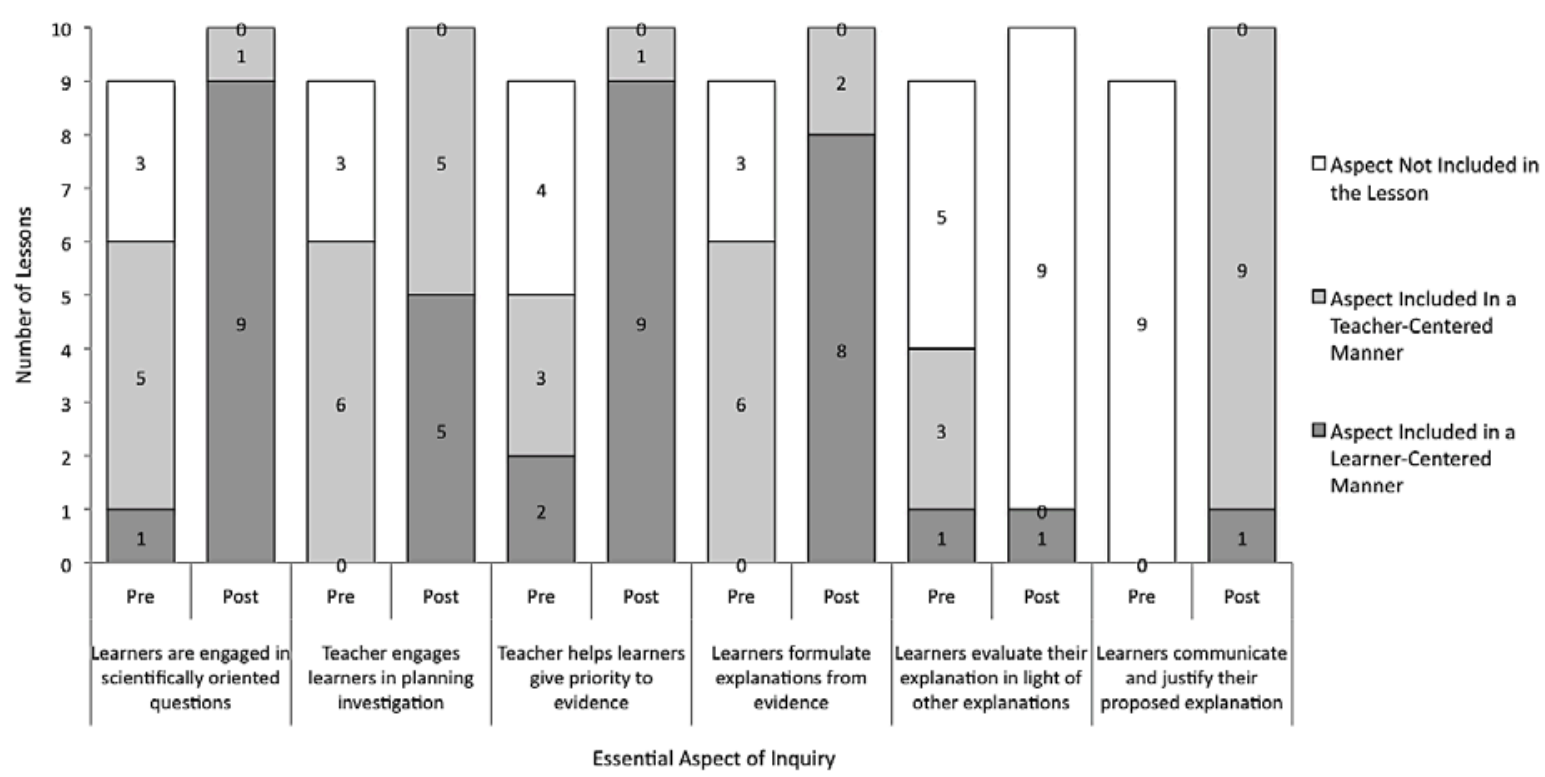

Figure 4. Number of lessons pre and post intervention that included an essential element of inquiry as defined by the National Science Education Standards. Note. One teacher did not submit a lesson pre program

There were also a greater proportion of lessons that included an aspect of the inquiry that was more learnercentred in nature after the program. Six of the lessons submitted pre program, for example, engaged students in scientifically oriented questions (see Figure 4) related to such things as fruit flies, gas laws, physical and chemical changes, and betta fish. However, five of these lessons did so in a teacher-centred manner (e.g., providing a question for all students to investigate, with expected results). For example, Sherilyn provided the procedures and protocols for her students to investigate vials of fruit flies, which they crossed and predicted phenotypic outcomes to answer predetermined questions. The following segment illustrates how Sherilyn framed the lesson pre-program.

Teacher: Can you hold that vial up and I want to zoom in on the flies. (Shows flies moving around in vial.) Thank you. (Her students are getting ready to draw the life cycle of drosophila melanogaster. They are making life cycles by observing the vials of fruit flies.) We have vestigial winged and normal winged flies. Also this week, we will be crossing the flies and predicting the phenotypic outcomes. You will be answering questions.

Student: We've got to draw this picture?

Teacher: The life cycle? Yes. On one side the life cycle and on the other a Venn diagram describing the differences in the male and female fruit fly.

Student: Do we have to draw both flies?

Teacher: You can, or you can just draw one.

Student: Do we have to draw both flies in the life cycles?

Teacher: You can draw one fly in the life cycle or both flies. They are both different sizes, so you might want to draw both.

In this pre-program lesson, Sherilyn has a student hold up a vial with two fruit flies and tells them that they "have vestigial winged and normal winged flies." Then, they are to "draw the life cycle" of the flies, "describing the differences in the male and female fruit fly." They will also make predictions of resulting crosses and answer questions. Despite the presence of the fruit flies, all of these student activities require them to make simple observations and predictions, under the direction of the teacher.

After the program was complete, however, nine of the lessons used a more learner-centred method to engage students in a scientifically orientated question (e.g., allowing students to generate questions to investigate after introducing them to a puzzling phenomenon). For example, Charity had her students develop testable questions about betta fish behaviour. Here is a short transcript of that lesson, post program. We pick up after students have been observing behaviours of betta fish in different tanks:

Teacher: Okay, so, let's hear some ideas on how we could experiment over colours and aggression and what we could possibly do.

Student: We could stick a male and a female in the same bowl? 
Table 4. Results for the teacher enactment of inquiry $2 \times 3$ contingency table analysis

\begin{tabular}{lccc}
\hline Aspect of Inquiry & $\mathbf{X 2}$ & P & Cramer's V \\
\hline Learners are engaged in scientifically-orientated questions & 9.09 & .011 & .69 \\
\hline Teacher engages learners in planning an investigation & 8.06 & .018 & .65 \\
\hline Teacher helps learners give priority to evidence & 9.43 & .009 & .7 \\
\hline Learners formulate explanations from evidence & 13 & .002 & .83 \\
\hline Learners evaluate their explanation in light of other explanations & 4.1 & .129 & - \\
\hline Learners communicate and justify their proposed explanations & 19 & $<.001$ & 1.0 \\
\hline
\end{tabular}

Teacher: Okay, well we can't stick them in the same bowl but we can [put them next to each other]. So, one of your ideas is if they're male and female.

Student: Mmhmm

Teacher: Okay, so pair males and males, males and females, so yours is, what you're asking I think is, does sex type play a role in aggression?

Student: Yeah

Teacher: Okay, so that would be your leading question. That would be your question before you made the hypothesis and then you have to make your own hypothesis I'm not gonna give it to you. So I want you to make a hypothesis as to what you think would happen.

Teacher: [Walking around to groups.] Okay, what about, what kind of project would you like to do?

Student: I don't know

Teacher: Okay, we know we're going to do something with aggression right? That's what seems like what the majority of the class is interested in. What other things could we do with aggression maybe?

In the above exchange, Charity begins by saying, "Let's hear some ideas on how we could experiment." One of the students suggests, "We could stick a male and a female in the same bowl" and rather than tell the student, the Charity responds with, "So, one of your ideas is if they're male and female." By asking students to make observations to develop their own research questions, and not providing the answers, Charity is modelling the learner-centred inquiry of the RET Program. This essential feature of inquiry, engaging students in a scientifically orientated question, was observed in all but one post program inquiry lesson.

To determine if the observed differences in the pre and post program lessons were statistically significant or not, we conducted a $2 \times 3$ contingency table analysis on each aspect of inquiry-based instruction. The two variables included in each analysis were time with two levels (pre and post participation in the program) and aspect with three levels (not included, included and teacher-centred, and included and learner-centred). The results of the six comparisons are provided in Table 4. The proportion of lessons that included an essential aspect of inquiry after the program was significantly different for each aspect except for aspect five (learners evaluate their explanation in light of other explanations). These results, overall, indicate that the lessons that were submitted after the program contained more of the essential aspects of inquiry than the lessons submitted before the program began.

\section{Which Aspects of the Science Pedagogy-Focused RET Program Seemed to Contribute to Changes in Teacher Thinking and Practice?}

The six-stage inquiry-based instructional model was first used by the scientists in the RET program to engage the science teachers in a guided inquiry, and each step of the model was then explicitly highlighted to the teachers during reflective sessions that took place after the inquiry. The teachers were then encouraged to use this six-stage model to develop their own inquiry-based lesson. As a result, the lessons developed and submitted by teachers post program were often well aligned with this model. As can be seen in Figure 5, when compared to the inquiry stages modelled in the RET, most post program lessons included the fieldwork (9), debriefing (9), experimentation (8), and data analysis (9) stages of the scientists' inquiry-based instructional model; few of the lessons included these stages pre-program.

The post program lessons designed by the teachers engaged students in their own scientifically orientated questions and gave them an opportunity to design their own investigations, formulate their explanations from evidence, and communicate their results. These lessons, however, did not give the students an opportunity to evaluate their explanations in light of other explanations, a stage that had not been modelled in the RET. In other words, the lessons designed by the teachers after the program reflected the two investigations they engaged in during the RET program and the RET instructional model. The teachers also adopted the language used by the scientists during the program to describe the various aspects of inquiry in their questionnaires, terminology that was absent in pre-program responses, but present in post program questionnaire data (see Table 5). 


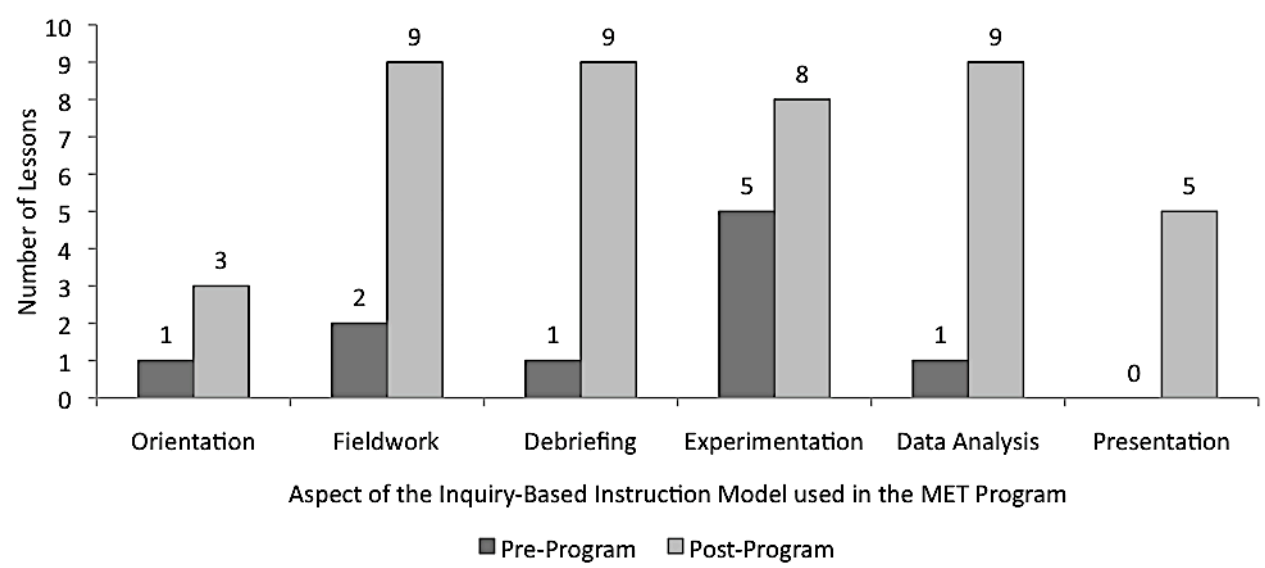

Figure 5. Aspect of the inquiry-based instruction model introduced in the RET model included the teacher's lesson before and after the program

Table 5. Illustrations of New Terminology present only on Post Program Questionnaires

\begin{tabular}{|c|c|c|}
\hline $\begin{array}{l}\text { RET Word / Term present } \\
\text { only post program }\end{array}$ & Teacher Quote & Teacher(s) who used it \\
\hline Reflect & $\begin{array}{l}\text { "Once orientation is complete they [scientists] begin to reflect on } \\
\text { their observations..." }\end{array}$ & Patrisha \\
\hline Data Graphs & "These conclusions are then arranged in a series of data graphs" & Patrisha \\
\hline Further Investigations & $\begin{array}{l}\text { "Once these steps are completed scientists then identify questions } \\
\text { for further investigations." }\end{array}$ & Patrisha \\
\hline PowerPoint presentations & $\begin{array}{l}\text { "I would better organize and prepare my students for PowerPoint } \\
\text { presentations." }\end{array}$ & Mason (and Patrisha) \\
\hline Student...Ownership & $\begin{array}{l}\text { "...students were involved in experiments that they developed and } \\
\text { had ownership of, which made them want to know the outcome." }\end{array}$ & $\begin{array}{l}\text { Charity (and Patrisha \& } \\
\text { Phillip) }\end{array}$ \\
\hline Key Components of inquiry & $\begin{array}{l}\text { Orientation, fieldwork, debriefing, experimentation, data analysis, and } \\
\text { presentation }\end{array}$ & Sherilyn (and Patrisha) \\
\hline Provocative Phenomenon & $\begin{array}{l}\text { "I define an inquiry investigation as a systematic process for getting } \\
\text { an answer to an investigable question about a provocative } \\
\text { phenomenon (discrepant event) that is staged by the teacher..." }\end{array}$ & Phillip \\
\hline Tool Shop & $\begin{array}{l}\text { "A 'tool shop' introduction... seemed to also help to expedite rocket } \\
\text { construction." }\end{array}$ & Phillip \\
\hline
\end{tabular}

\section{LIMITATIONS}

Our findings need to be viewed in light of several limitations. First, we are unable to rule out all potential alternative explanations for the observed differences in teacher thinking and lesson design after the program due to the nature of the research design. Second, our choice of outcomes and how we decided to measure them provides us with only a limited picture of what the teachers learned during the science pedagogy-focused RET. Our findings, as a result, may have differed if we chose to target different learning outcomes. Third, the number of participants in this study was small and the nature of their experience during the RET was unique. The generalizability of our findings, therefore, might be limited to this single case. Fourth, we only analyzed two lessons that were designed and taught by these teachers. One lesson was taught before the program and one was taught after it. In addition, the teachers designed the inquiry-based lesson that was taught after the program during the program. We therefore cannot make any claims about how often these teachers designed and taught inquiry-based lessons after the program and the nature of these lessons. With these limitations in mind, we will now discuss the findings of this study in light of the available literature.

\section{DISCUSSION}

The teachers who participated in this study described inquiry in terms of their personal experiences rather than in terms of how it is conceptualized and described in the science education literature. These teachers, in other words, often wrote about what they and their students did when in the classroom, the content they covered during a lesson, and issues related to assessment but did not mention any of the essential aspects of inquiry outlined by 
the NRC (2000). This observation is consistent with Gallagher and Parkers' (1995) and Blanchard's (2006) descriptions of how teachers tend to think about inquiry. Our analysis of the way the teachers responded to the different items on the questionnaire before and after the RET program indicated that the teachers conceptions of inquiry only changed on two of the five aspects of inquiry that we examined during this study. These aspects included the role of assessment in the context of inquiry and student actions inside the classroom (see Table 3 and Figure 3). This finding is interesting because many of the responses given by the teachers on the questionnaire before the program where already learner-centred. The significant change in the proportion of learner-centred comments about the role of assessment and the nature of student actions inside the classroom is therefore notable. The observed difference in their views about assessment was likely due to the fact that assessment was not a strong focus of these teachers when considering inquiry in the past, and was focused on what they, the teacher would do to assess. Abrams, Southerland, and Evans (2007) have provided a model of inquiry that suggests a focus on the learning of content reduces more open-ended science inquiry investigations. Post RET, students were sharing results of their studies, as modelled in the RET, but this did not seem to correspond to the teachers' views of assessment, as only two of teachers' post RET questionnaire responses were coded as addressing the role of assessment. This finding is consistent with research that describes teachers' focus on assessment in contrast to those practices (such as inquiry) that increase student understanding (e.g., Pringle \& Carrier Martin, 2005; Saka, Southerland, \& Brooks, 2009). The positive change in teachers' conceptions of student actions inside the classroom, in contrast, was likely due to the fact that these ten teachers had an opportunity to learn from and about inquirybased instruction during the RET program. This direct and sustained experience with inquiry-based instruction seemed to encourage these teachers to think about what students do inside the classrooms during inquiry because they could actually imagine the roles students would have and what they would be able to do during a lesson, based on their personal experiences. These explanations, however, are only speculative and will require additional research to substantiate.

The lessons that were submitted by the teachers after the program contained more essential aspects of inquiry outlined by the NRC (2000) than the lessons they submitted before they participated in the science pedagogyfocused program. The only essential aspect of inquiry that was not included in the lessons more after the program was element four (learners evaluate their explanation in light of other explanations). The stages present in the teachers' lessons also mirrored all of the stages of the inquiry-based instructional model used in the RET (see Table 4 and Figure 4) including the notable fact that the NSES 'Learner connects explanations to scientific knowledge' was not present in the RET instructional model and also not present in the teachers' inquiry-based lesson. This pattern of adoption of some essential elements of inquiry but not others in the teachers' lessons provides strong evidence that teachers are able, and willing, to use an instructional approach that is modelled during an RET program to guide the way they design lessons once back in the classroom. Our analysis of the questionnaire responses also suggests strong links to the language used by the scientists during the RET and the stages of inquiry modelled. Indeed, teachers incorporated many aspects of the terms used by the scientists during the RET into their post-program questionnaire responses (see Table 5). These results, overall, suggest that the inquiry-based instructional model introduced to the teachers during the RET helped to shape the nature of the inquiry lessons implemented by the classroom teachers.

It was surprising to find that the teachers' conceptions of inquiry had changed less than their enactment of inquiry in their lessons. However, as we highlighted earlier, many of the teachers' inquiry conceptions at the beginning of the program were already learner-centred. Their lessons also lacked many if not all of the essential aspects of inquiry. We then observed modest changes in their beliefs about inquiry but substantial changes in teaching practices after the program. Given the literature that teachers' beliefs often are described as needing to change in order for there to be changes in their practices (e.g., Anderson, 2007; Crawford, 2000; Lotter, Harwood, and Bonner, 2007), it was interesting to see that more student-centred practices were included in the post RET program lesson than we anticipated. This observation, however, also suggests that beliefs may be a poor predictor of current or future teacher classroom practice. Half of the participating teachers' described conceptions about teaching and learning inquiry that were learner-centred both before and after the program, but most of the teachers $(n=9)$ designed and taught lessons that were consistent with the essential aspects of inquiry outlined by the NRC (2000) after the program. This finding suggests that this group of teachers did not know how to design inquirybased lessons, or at least did not know how to design lessons that were consistent with the essential aspects of inquiry outlined by the NRC (2000), before the program - even though they had many learner-centred beliefs that were consistent with inquiry-based instruction. This finding might help explain why interventions that are designed to change the beliefs of teachers often do not lead to a major change in classroom practice (Capps \& Crawford, 2013; Enderle et al., 2014; Sadler et al., 2010). In other words, learner-centred beliefs about teaching and learning might be a necessary but insufficient characteristic of teachers if the goal of an intervention is to change teacher practice, resonant with the recommendation of Capps and Crawford (2013) for more participation in scientific research. We posit that teachers seem to need instructional models that they can use to guide how they design and implement lessons before they will actually change their practice. 
It is important to point out, however, that many of the teachers in this study designed a lesson that excluded an essential aspects of inquiry (e.g., leaners evaluate evidence in light of other explanations) or carried out an aspect of inquiry in a teacher-centred way (e.g., learners communicate and justify their proposed explanation) after the program. This observation could be viewed as an unexpected result given the fact this group of teachers worked in a pedagogy-focused RET all summer to design and hone their lessons. The lessons they designed, however, were consistent with the inquiry-based instructional model that was used during the program. This finding suggests that the instructional model used during a pedagogy-focused RET shapes how the teachers who participate in that program think about inquiry. This explanation is also consistent with the way teachers use their personal experiences to describe what counts as inquiry rather than the way inquiry is conceptualized and described in the science education literature (e.g., Capps et al., 2016; Gallagher \& Parker, 1995). The model of inquiry that was used during the RET program, as a result, became the model that these teachers used to define what does and what does not count as inquiry-based instruction. Therefore, the teachers' lessons post program did not give students an opportunity to evaluate evidence in light of other explanations because the instructional model used during the RET program did not include this element even though it is considered an essential element of inquiry in the science education literature.

These findings, when taken together, are important because the overall goal of RET programs is to "build longterm collaborative partnerships between K-12 STEM teachers...in...research and helping them translate their research experiences and new knowledge into classroom activities" (NSF, 2017). Current research, however, indicates that many RET programs or other authentic experiences with scientists have little effect on teachers' instructional practices (Enderle et al., 2014; Sadler et al., 2010) even though they tend to improve teachers' knowledge of scientific practices (Feldman et al., 2009; Southerland et al., 2016), beliefs about inquiry-based teaching (Capps \& Crawford, 2013; Enderle et al., 2014), and their self-efficacy about using inquiry-based instruction (Enderle et al., 2014). Our findings indicate that a focus on science pedagogy during an RET is just as important, or perhaps more important, than a focus on the nature of scientific research. It appears that teachers need to be introduced to an inquiry-based instructional model that they can use to design their own lessons when they return to the classroom as part of the RET experience. Without this key element, teachers may be unable to "translate their research experiences and new knowledge into classroom activities." The theory of action underlying many science-research focused RETs that we outline earlier (see Figure 1), as a result, might be fundamentally flawed.

\section{IMPLICATIONS}

Our findings have a number of important implications for science teacher education because they suggest that the beliefs of the teachers who participated in this study were a poor predictor of their instructional practices before and after the pedagogy-focused RET program. Observed changes in the beliefs and practices of the science teachers who participated in this study were associated with a specific feature of the pedagogy-focused RET or a specific event that took place during the program. This study also has a number of important implications for future research on teacher learning and the design of new RET programs in light of our findings. In this section, we will examine these implications.

\section{Implication for the Design of future RET Programs}

The findings from this study suggest that researchers should reconsider the basic theory of action underlying many traditional science-research focused RET programs (see Figure 1) and adopt one that is more aligned with the assumptions underlying a science-pedagogy focused RET program. In science pedagogy-focused RET programs, such as the one described in this study, teachers learn about the nature of scientific research and inquirybased instruction. An example of a theory of action that focuses on research and instruction at the same time is provided in Figure 6. In this theory of action, the malleable factor, or the characteristics of a teacher that is the target of the intervention, is knowledge of scientific inquiry and the ability to create inquiry-based lessons. The intervention is still an apprenticeship with a practicing scientist. The focus of the intervention, however, involves more than an opportunity to work with scientists on a research project. The teachers instead experience doing inquiry as students would through an inquiry-based instructional approach and learn how to design lessons using the same model. The proximal outcome is improved teacher knowledge of scientific research and an improved understanding of how to design inquiry-based lessons. The teachers are then expected to use this knowledge and these new skills to create and implement lessons that give students an opportunity to participate in the practices of science. This component of the theory of action is a mediating factor because the nature of the lessons affects what students learn, which is the final outcome of the program. 


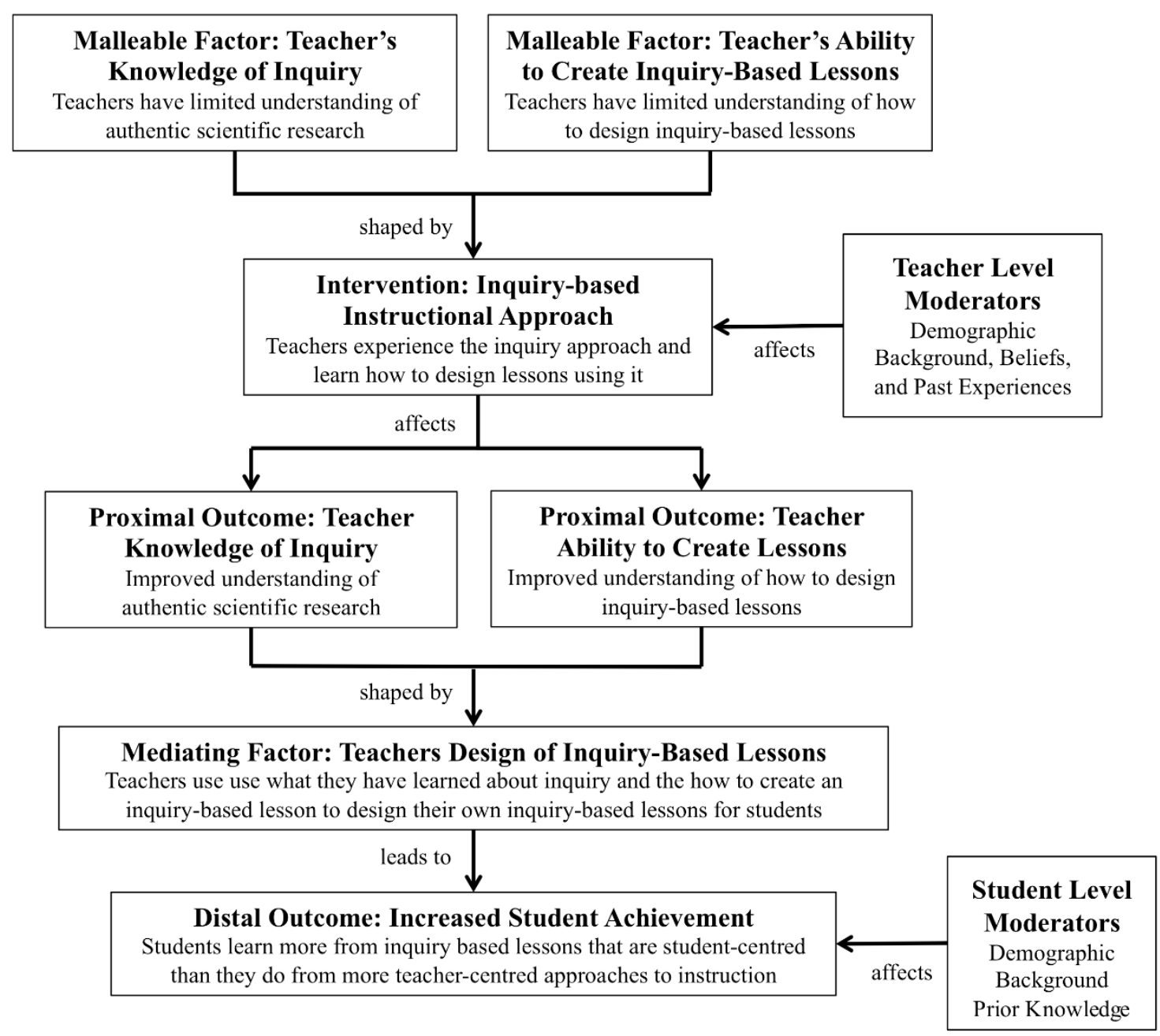

Figure 6. The theory of action underlying a science pedagogy-focused RET model

This theory of action, we argue, has the potential to address many of the shortcomings of traditional RET programs that are designed to give teachers an apprenticeship into scientific research. In this sort of science-research focused RET, the mentor (a practicing scientist) works actively with the apprentice (a teacher) in order to help make his or her reasoning behind the tasks that they perform during a specific study visible during the intervention. By making his or her thinking visible, the apprentice can understand the purpose of what they are learning, which enables the apprentice to use this new knowledge of how certain tasks are done and why they are done in specific ways in different but related contexts (Collins, Brown, \& Holum, 1991). Unfortunately, the teachers only learn about the purpose of tasks related to research but not teaching during a science research-focused RET. The teachers, as a result, are left on their own to figure out how to apply their knowledge of research to the design of an inquirybased lesson once they return to the classroom. This type of research-focused intervention, as result, often has little effect on classroom practice (e.g., Capps et al., 2012; Silverstein et al., 2009). The theory of action outlined on Figure 6 , in contrast, focuses on the nature of scientific research and inquiry-based instruction at the same time, so the reasoning behind tasks related to both research and teaching are made visible to the teachers during the RET by the mentor. The teachers, as a result, not only learn more about scientific research but are also guided through the process of translating their research experiences into actual classroom lessons. This, we hope, will lead to lasting improvements in the inquiry teaching in science classrooms following RETs.

\section{Implications for Science Teacher Education}

Although this research was conducted with classroom teachers, we suggest there might be implications for the preparation of teachers who are learning to implement inquiry in their future science classrooms. The literature suggests that students may be leaving their preservice experiences with reform-based beliefs about teaching, but when they encounter their classrooms and contextual influences of their schools, they can resort to more traditional, 
teacher-centred instruction (e.g., Crawford, 2007; Luft, Firestone, Wong, Ortega, Adams, \& Bang, 2011). We posit that we might be focusing too much on teacher beliefs, rather than giving teachers concrete models for developing inquiry-based lessons. Perhaps providing more instructional models and helping preservice teachers to revise existing lessons, with the guidance and feedback of science educators, could help these preservice teachers' reformminded beliefs to be implemented once they are in classrooms.

\section{Implications for the Future Research on Teacher Learning}

Sustaining a study of RET teachers over more lessons and more time (multiple years) would likely help to ensure that the results of the RET are lasting (Luft, 2007). Given the promising results of Blanchard, LePrevost, Tolin, and Gutierrez (2016), we recommend that a group of teachers from the same school are recruited to participate in RET experiences, providing more classrooms with reform-based models of science inquiry, rather than 'filling seats' in RETs with teachers from as many as 24 different schools, as was the case in this project. We expect that students' prolonged experiences with multiple science teachers over multiple years may result in better student understanding of science inquiry and conceptual learning. We also believe that teachers' prolonged teaching of these lessons are more likely to result in their prolonged use of inquiry-based practices. In order to know if this is the case, we recommend that these experiences are studied.

\section{ACKNOWLEDGEMENTS}

This research was funded in part by the National Science Foundation ESI-9819431. Any opinions, findings, and conclusions or recommendations expressed in this material are those of the authors and do not reflect the views of the National Science Foundation.

\section{REFERENCES}

Abrams, E., Southerland, S. A., \& Evans, C. (2007). An introduction to inquiry. In E. Abrams, S. A. Southerland, \& P. Silva (Eds.), Inquiry in the classroom: Realities and opportunities (pp. i - xiii). Greenwich, CT: Information Age Publishing.

Anderson, R. D. (2007). Inquiry as an organizing theme for science education. In S. K. Abell \& N. G. Lederman (Eds.), Handbook of research on science education (pp. 807 - 830). Mahwah, NJ: Lawrence Erlbaum Associates.

Blanchard, M. R. (2006). Assimilation or transformation? An analysis of change in ten secondary science teachers following an inquiry-based research experience for teachers. (Doctoral dissertation). Retrieved from http://diginole.lib.fsu.edu/etd/3664.

Blanchard, M. R., LePrevost, C. E., Tolin, A. D., \& Gutierrez, K. S. (2016). Investigating technology-enhanced teacher professional development in rural, high poverty middle schools. Educational Researcher, 43(3), 207-220.

Blanchard, M. R., Osborne, J. W., Wallwork, C. \& Harris, B. S. (2013). Progress on implementing inquiry in North Carolina: Nearly 1,000 elementary, middle and high school science teachers weigh in. Science Educator, 22(1), 37-49.

Blanchard, M. R., Southerland, S. A., \& Granger, D. E. (2009). No silver bullet for inquiry: Making sense of teacher change following an inquiry-based research experience for teachers. Science Education, 93(2), 322-360.

Blanchard, M. R., Southerland, S. A., Osborne, J. W., Sampson, V. D., Annetta, L. A., \& Granger, E. M. (2010). Is inquiry possible in light of accountability? A quantitative comparison of the relative effectiveness of guided inquiry and verification laboratory instruction. Science Education, 94(4), 577-616.

Barnes, M. B., Hodge, E. M., Parker, M., Koroly, M. J. (2006). The teacher research update experience: Perceptions of practicing science, mathematics, and technology teachers. Journal of Science Teacher Education, 17, $243-263$.

Bodzin, A. M., \& Beerer, K. M. (2003). Promoting inquiry-based science instruction: The validation of the science teacher inquiry rubric (STIR). Journal of Elementary Science Education, 15(2), 39-49.

Capps, D. K. \& Crawford, B. A. (2013). Inquiry-based instruction and teaching about the nature of science: Are they happening? Journal of Science Teacher Education 24(3), 497-526.

Capps, D. K., Crawford, B. A., \& Constas, M. A. (2012). A review of empirical literature on inquiry professional development: Alignment with best practices and a critique of the findings. Journal of Science Teacher Education, 23(3), 291-318. doi:10.1007/s10972-012-9275-2

Capps, D. K., Shemwell, J. T., Young, A. M. (2016). Over reported and misunderstood? A study of teachers' reported enactment and understandings of inquiry-based science teaching. International Journal of Science Education, 38(6), 934-959. 
Chinn, C. A., \& Malhotra, B. A. (2002). Epistemologically authentic inquiry in schools: A theoretical framework for evaluating inquiry tasks. Science Education, 86, 175 - 218.

Collins, A. Brown, J. S. and Holum, A. (1991). Cognitive apprenticeship: Making thinking visible. American Educator, 6(11), 38-46.

Crawford, B. A. (2000). Embracing the essence of inquiry: New roles for science teachers. Journal of Research in Science Teaching, 37, $916-937$.

Crawford, B. A. (2007). Learning to teach science in the rough and tumble of practice. Journal of Research in Science Teaching, 44, $613-642$

Dresner, M., \& Worley, E. (2006). Teacher research experiences, partnerships with scientists, and teacher networks sustaining factors from professional development. Journal of Science Teacher Education, 17, 1 - 14.

Enderle, P., Dentzau, M., Roseler, K., Southerland, S. A., Granger, E., \& Hughes, R. (2014). Examining the Influence of RET's on Science Teachers' Beliefs and Practice. Science Education, 98, 1077-1108.

Erlandson, D. A., Harris, E. L., Skipper, B. L., \& Allen, S. D. (1993). Doing naturalistic inquiry. Newbury Park, CA: Sage.

Feldman, A., Divoll, K., Rogan-Klyve, A. (2009). Research education of new scientists: Implications for science teacher education. Journal of Research in Science Teaching, 46(4), 442-459.

Gallagher, J., Parker, J. (1995, October). Secondary Science Teacher Analysis Matrix (SSTAM). East Lansing, MI: Michigan State University.

Green, S. B., \& Salkind, N. J. (2005). Using SPSS for Windows and Macintosh: Analyzing and understanding data (4th ed.). Upper Saddle River, NJ: Pearson-Prentice Hall.

Lave, J. \& Wenger, E. (1991). Situated Learning: Legitimate Peripheral Participation. Cambridge: Cambridge University Press.

Lotter, C., Harwood, W. S., \& Bonner, J. J. (2007). The influence of core teaching conceptions on teachers' use of inquiry teaching practices. Journal of Research in Science Teaching, 44(9), 1318-1347.

Luft, J. A. (2001). Changing inquiry practices and beliefs: the impact of an inquiry-based professional development programme on beginning teachers and experienced secondary science teachers. International Journal of Science Education, 23(5), 517-534.

Luft, J. A. (2007). Minding the gap: Needed research in beginning/newly qualified science teachers. Journal of Research in Science Teaching, 44(4), 532-537.

Luft, J. A., Firestone, J., Wong, S. S., Ortega, I., Adams, K., \& Bang, E. J. (2011). Beginning secondary science teacher induction: A two-year mixed methods study. Journal of Research in Science Teaching, 49(10), 1199-1224.

MacIsaac, D. \& Falconer, K. (2002). Reforming physics instruction via RTOP. The Physics Teacher, 40(8), 479-485.

National Research Council. (2000). Inquiry and the national science education standards. Washington, DC: National Academic Press.

National Science Foundation. (2017). Research experiences for teachers (RETs) in engineering and computer science. Retrieved from https://www.nsf.gov/funding/pgm_summ.jsp?pims_id=5736

NGSS Lead States. (2013). Next generation science standards: For states, by states. Washington, DC: National Academies Press.

NGSS Release. (2013). Final Next Generation Science Standards Released. Retrieved from https://www.nextgenscience.org/news/final-next-generation-science-standards-released

Park, J., Jang, K., \& Kim, I. (2009). An analysis of the actual processes of physicists' research and the implications for teaching scientific inquiry in school. Research in Science Education, 39, 111-129.

Patton, M. Q. (2002). Qualitative Research \& Evaluation Methods. Thousand Oaks: Sage Publications.

Pop, M. M., Dixon, P. \& Grove, C. M. (2010). Research Experiences for Teachers (RET): Motivation, Expectations, and Changes to Teaching Practices due to Professional Program Involvement. Journal of Science Teacher Education, 21(2), 127-147.

Pringle, R. M., \& Carrier Martin, S. (2005). The potential impacts of upcoming high-stakes testing on the teaching of science in elementary classrooms. Research in Science Education, 35, 347-361.

Roehrig, G. H., \& Luft, J. A. (2004). Constraints experienced by beginning secondary science teachers in implementing scientific inquiry lessons. International Journal of Science Education, 26(1), 3-24.

Sadler, T. D., Burgin, S., McKinney, L., \& Ponjuan, L. (2010). Learning science through research apprenticeships: A critical review of the literature. Journal of Research in Science Teaching, 47(3), 235-256. 
Saka, Y., Southerland, S. A., \& Brooks, J. (2009). Becoming a member of a school community while working toward science education reform: Teacher induction through a cultural historical activity theory (CHAT) perspective. Science Education, 93(6), 996 - 1025.

Schön, D. (1987). Educating the reflective practitioner. San Francisco, CA: Jossey-Bass.

Silverstein, A. C., Dubner, J., Miller, J., Glied, S., \& Loike, J. D. (2009). Teachers' Participation in Research Programs Improves Their Students' Achievement in Science. Science, 326(5951), 440-442.

Southerland, S. A., Gess-Newsome, J., \& Johnston, A. (2003). Portraying science in the classroom: How scientists' beliefs are manifested in classroom practice. Journal of Research in Science Teaching, 40(7), 669 - 691.

Southerland, S. A., Granger, E. M., Hughes, R., Enderle, P., Ke, F., Chaminade, K. R., Saka, Y., \& Tekkumru-Kisa, M. (2016). Essential Aspects of Science Teacher Professional Development: Making Research Participation Instructionally Effective. AERA Open, 2(4), 1-16.

\section{http://www.ejmste.com}

